\title{
Normative Values of Some Morphometric Variables for Kosovo Albanian Population Aged $06->70$ Years Old
}

\author{
Valores Normativos de Algunas Variables Morfométricas para la Población \\ Albanesa de Kosovo de Edades Comprendidas entre los 6 y los 70 Años
}

Agron M. Rexhepi; Behlul Brestovci \& Imran Isufi

REXHEPI, A. M.; BRESTOVCI, B. \& ISUFI, I. Normative values of some morphometric variables for Kosovo Albanian population aged 06 - >70 years Old. Int. J. Morphol., 36(2):592-597, 2018.

SUMMARY: The purpose of this study was to find out normative values of the Body Height, Body Weight, Body Mass Index and Basal Metabolic Rate, as well as to study, observe and to clarify the dynamics of physical growth and changes. Four anthropometric variables were measured in 94825 male Albanian entities from Kosovo aged 06->70 years old, during the period 2007-2016. The same variables were measured in 409 sportsmen from Kosovo. The obtained data were analysed through Descriptive Parameters (arithmetic mean, maximum, minimum and standard deviation) and Correlation Analysis. Gained results indicate average to high Body Height of measured male Kosovo Albanians (50.6\% of entities = 1700-1799 mm; 38.2 \% = 1800-1899 mm). The smaller entity with body height $1015 \mathrm{~mm}$ belongs to age-group of 6 years old, while the higher entity with $2015 \mathrm{~mm}$ belongs to the age group of 19 years old. The correlation coefficient between Body Height and Body Weight shows its higher values in two phases of intensive body growth (0.71$0.76)$ and in the decrease phase of the body morphometry (0.57-0.65). Kosovo Albanian sportsmen aged 17-25 years with average Body Height=1847.75 $\mathrm{mm}$ and Body Weight=75.87 kg belongs to group of higher people with ideal body weight.

KEY WORDS: Body height; Body weight; Body mass index; Basal metabolic rate.

\section{INTRODUCCIÓN}

Body height and body weight are two morphometric measurements, which are very close concepts to one another and inform the human growth and development. While body height (stature) is a linear anthropometrical measurement (linear longitudinal dimension) the body weight is a three morphometric dimensional measure (the composition of the longitudinal, transversal and the body volume dimension) (Rexhepi et al., 2011).

The human body height and body weight have been the main purpose of many studies across different fields of anthropological sciences. These morphometric variables are directly determined by genetic, environmental and socioeconomic factors (Rexhepi \& Brestovci, 2010). Also, these variables are highly correlated with some health conditions, respectively with risk to certain diseases (Bray, 2004; Fagaras et al., 2015).

The body height determination is over $80 \%$ controlled by genetic factors, and about $20 \%$ by external factors (various socio-economic conditions, mental status, culture, climate and season, physical activities, certain diseases, environment factors, nutritional factors, etc.) (Sammalisto, 2008; McEvoy \& Visscher, 2009; Rexhepi et $a l$.). Although decades ago the researchers have emphasized the involution of the genetic factor in the determination of the body height, recent advances methods in technology in searching of the human genome have found that about 50 genes and regions of the genome are associated with body height (McEvoy \& Visscher). Over the past few decades, due to the improvements in health and nutrition, the human height has continually increased.

Recent studies indicate that the body weight is about 40-70\% determined by the genetic factors (Wardle et al., 2008). According to Herrera et al. (2011) " ... more than 40 genetic variants have been associated with obesity and fat distribution".

The changing of the body shape during age-related human growth is mostly described using the body mass index (BMI). The BMI describes the human body shape, 
respectively body composition based on the proportions between body weight (BW) and body height (BH) (Fagaras et al.; Rexhepi et al.). These morphometric variables are directly affected by age and sex.

The information collected from anthropometric measurements enables a reliable study of the anthropological status of the nations. Also, according to these measurements, it can be compared the anthropological features of the today's nations and previous nations too (Coon, 1939; Dhima, 2017).

Although from the anthropologists' view the human is an undivided psycho-somatic entity, the body height is most often measured for purposes of ethno-anthropological researches.

The fact that the Albanian population lives in territories that belong to mountain chain known as Dinarides or the Dinaric Alps (Italy, Slovenia, Croatia, Bosnia and Herzegovina, Serbia, Montenegro, Albania) has sparked the curiosity of many anthropologists to study the morphological type of the Albanians (Coon, 1950). The pioneers of anthropological studies on Albanians are Weisbach (1877) and Glück (1897). Data drawn from history and from archaeological and anthropological studies have led researchers to consider the Albanians to be the direct descendants of the ancient Illyrians (Enciclopedia Britanica, 2017).

The main purpose of the present study was to discover the normative values of the body height, body weight, Body Mass Index, and Basal Metabolic Rate of Kosovo Albanian population aged 6 - >70 years old. The other purpose of this study was to study, to observe, and to clarify the dynamics of physical growth and changes of the body height, body weight, body mass index and basal metabolic rate, as well as to explore the relation between these variables.

\section{MATERIAL AND METHOD}

This study is an observational, cross-sectional descriptive study and a part of a larger comprehensive project. This project "The exploration of the anthropological status of Kosovo population" was carried out at the Institute of Sports Anthropology - Centre for Sport, Fitness and Nutrition 'Corpore Sano' in Prishtina, Kosovo.

Following the protocols of the International Biological Programme were measured four morphometric variables on 94825 male Albanian entities from Kosovo aged 06 - >70 years old. The examined entities were chosen randomly, always respecting the rule that their psychophysical condition was in the normal range, with no obvious deformities or previous history of any trauma of spine and limbs. The measurements were done during the period of time 2007 - 2016. As the body height and the body weight show diurnal variation (stature is greatest in the morning, whilst body weight is lighter) the entities were measured in the morning $(08.00-11.00 \mathrm{AM})$.

\section{Measured variables:}

- Body Height (BH) - indicates the distance from the standing surface to the vertex of the head, with subject's body position in a standard erect posture, without shoes, and with head position in Frankfort horizontal plane. Stature was measured with a classical anthropometer and was expressed in $\mathrm{mm}$.

- Body Weight (BW) - was measured with a digital weighing scale and was expressed in $\mathrm{kg}$.

- Body Mass Index - BMI (expressed in $\mathrm{kg} / \mathrm{m}^{2}$ ) is defined as the ratio between the body mass $(\mathrm{kg})$ and the square of the body height $\left(\mathrm{m}^{2}\right)$ :

$$
\mathrm{BMI}=\mathrm{BW}(\mathrm{kg}) / \mathrm{BH}^{2}(\mathrm{~m})
$$

- Basal Metabolic Rate (BMR) expressed in kcal was calculated according to the Mifflin-St. Jeor equation:

$\operatorname{BMR}=(10 \mathrm{x}$ weight $(\mathrm{kg}))+(6.25 \mathrm{x}$ height $(\mathrm{cm}))-(5 \mathrm{x}$ age (years) $)+5$

The statistical analyses were performed with the IBM SPSS Statistics software package, version 20. The obtained data were analysed in terms of descriptive statistical parameters (Mean, Minimum and maximum value, Standard Deviation).

Ethical considerations. This project was approved by the Ethics Committee of the Institute of Sports Anthropology. The authors declare no conflict of interest and no financial or commercial benefits for the performing of this study.

\section{RESULTS AND DISCUSSION}

The data of Table I contains descriptive parameters (Mean, Maximum, Minimum and Standard Deviation) of the Body Height and the Body Weight of measured entities. Last column of this table shows the correlation between the Body Height and the Body weight. Data of the Table I show changing values of these two morphometric variables during different ages. 
Analysing these data it can be differentiated different phases of morphometric development such as:

\section{Two intensive phases of growth and development:}

- Age groups 7-8 yr. are characterised with intensive increases in the Body Height $(\mathrm{BH}=56.2 \mathrm{~mm})$ and the Body Weight $(\mathrm{BW}=3.3 \mathrm{~kg})$, as well as with an increased correlation (0.74-0.76) between these two morphometric variables.

- Age groups 13-14-15 years old:

- BH 13-14 years old = +77.9 mm; BW 13-14 years old = $+6.6 \mathrm{~kg}$.

- BH 14-15 years old $=+63.5 \mathrm{~mm}$; BW 14-15 years old $=$ $+6.4 \mathrm{~kg}$.

- The phase of maximal achieved values of the $\mathrm{BH}$ and the BW

- Age groups 24-25 year old. are characterised with maximal achieved values of the $\mathrm{BH}(1787.79 \mathrm{~mm})$ and the BW $(75.35 \mathrm{~kg})$, as well as a minimal differentiation between two ages $(\mathrm{BH} 24-25$ years old $=+0.78 \mathrm{~mm}$; BW 24-25 yr $=+0.52 \mathrm{~kg}$ )

- The decrease phase of the body morphometry (Body Height and Body Weight)
- Age groups 60-69 years old and $>70$ years old shows the higher differentiation between measured entities

- The Body Height (BH) differentiation between two age groups (60-69 years old and $>70$ years old) is decreased for $68 \mathrm{~mm}$;

- The Body Weight (BW) differentiation between two age groups (60-69 years old and $>70$ years old) is decreased for $16.64 \mathrm{~kg}$.

The correlation coefficient between two measured morphometric variables (Body Height and Body Weight) shows its higher values in two phases of intensive body growth and in the decrease phase of the body morphometry (Table I).

Mean values of Body Height and Body weight, shown in Table I, may be considered as standard values of Kosovo Albanian population. According to the data of the table I the higher mean values of the Body Height and the Body Weight have realized entities of the age groups 24 and 25 years old. According to these results, the average Body Height of the measured entities of these age groups was $\mathrm{BH}=1787.4 \mathrm{~mm}(\mathrm{BH} 25 \mathrm{yo}=1787.79 \mathrm{~mm}$, variation Maxi=1994 $\mathrm{mm}$ and Mini=1610 mm;

Table I. Descriptive parameters of the Stature and the Body Weight for different age groups.

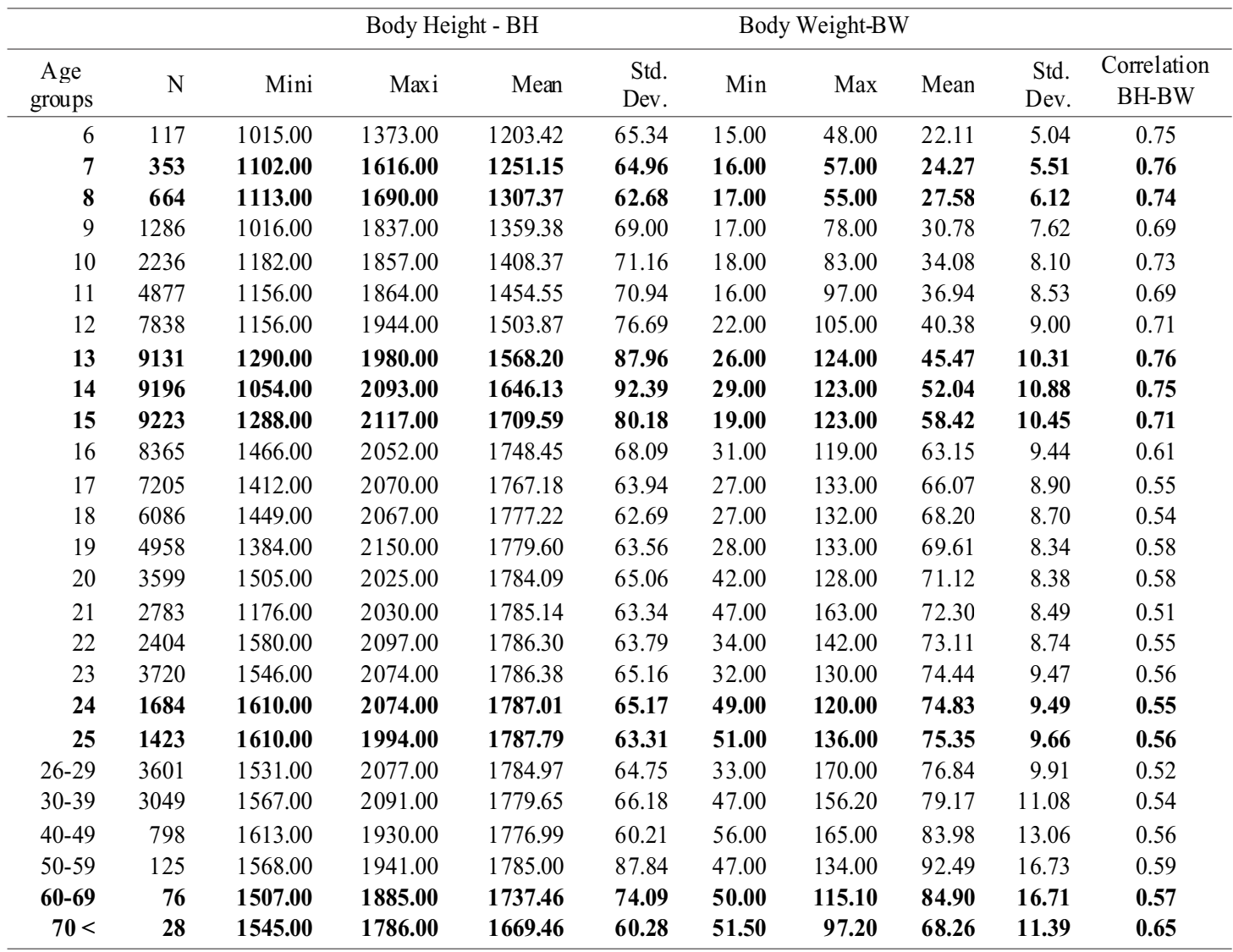


BH24yo $=1787.01 \mathrm{~mm}$, variation $\mathrm{Maxi}=2074 \mathrm{~mm}$, Mini=1610 mm); the average Body Weight of these entities were $\mathrm{BW}=75.01 \mathrm{~kg}(\mathrm{BW} 25 \mathrm{yo}=75.35 \mathrm{~kg}$, variation Maxi $=136 \mathrm{~kg}$ and Mini $=51 \mathrm{~kg}$; BW24yo $=74.83 \mathrm{~kg}$, variation Maxi $=120 \mathrm{~kg}$, Mini=49 kg) (Table I).

Data of Table II shows the normal dispersion of the measured entities within age-groups according to their body height. According to this data, most of the measured entities belong to the group of entities with average to higher body height (Table II, Fig. 1).

Table II. Dispersion of the population aged 24-25 years old according to body height.

\begin{tabular}{lcc}
\hline Body Height & Nr of entities & \% within age group \\
\hline $1610-1699 \mathrm{~mm}$ & 224 & 7.2 \\
$1700-1799 \mathrm{~mm}$ & 1572 & 50.6 \\
$1800-1899 \mathrm{~mm}$ & 1186 & 38.2 \\
$1900-1999 \mathrm{~mm}$ & 120 & 3.8 \\
$>2000 \mathrm{~mm}$ & 5 & 0.2 \\
Total & 3107 & 100.0 \\
\hline
\end{tabular}

\section{Nr of entities}

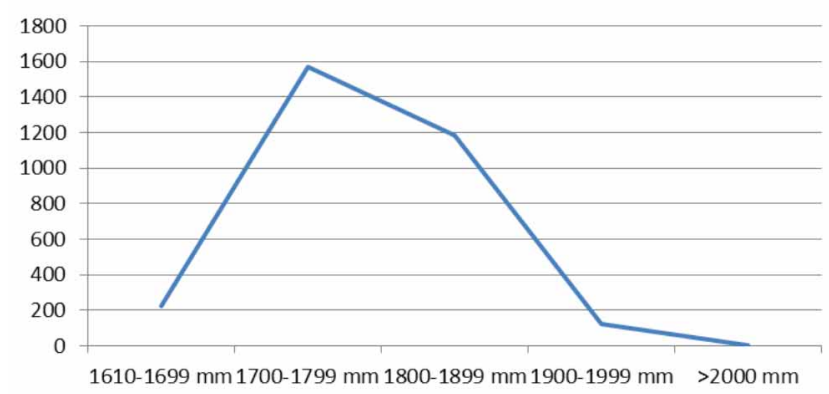

Fig. 1. Dispersion of the population aged 24-25 years old according to body height.

Descriptive data (mean values, minimum values, maximum values and standard deviation) of Body Mass Index (BMI) and Basal Metabolic Rate (BMR) during different ages from 6 - >70 years old are shown in Table III. Data of this table contain the values of the correlation coefficient between these two morphometric variables. Although mean values of BMI indicates a normal body weight for all age groups from 6 to 39 years old, the age groups 40 - 69 years old are characterized as slightly overweight people. Also, data of BMI show increase of these data in almost all age groups (6-69 years old), except in age group $>70$ years old.

According to the data of Table III, Basal Metabolic Rate shows in continuum its increasing values from the age group of 6 years old until the age group of 18 years old. From the age group of 18 years old to the age group of 50-59 years old the Basal Metabolic Rate shows relatively stable values $(1708.9-1777.6 \mathrm{kcal})$. While the age groups above 60 years old compared with younger age groups show rapid decreasing of the Basal Metabolic Rate values.

The correlation between Body Mass Index (BMI) and Basal Metabolic Rate (BMR) was found to be higher among age groups 6-15 years old and above 40 years old (40 - >70 years old), while a moderate and stable correlation between these two variables was found in age groups 1639 years old (Table III).

Figure 1 shows in graphic form the mean values of the Body Height in different age groups (from the age group of 6 years old to $>70$ years old). The up-growth part of the curvature show the increased phase (group of children and adolescents aged 6-17 years old), the horizontal part of the curvature show stable phase of Body Height (group of mature ages $18-59$ years old) and the declining part of curvature indicates the decreased phase of the Body Height (older entities above 60 years old).

Since the athletes represent a group of entities with particular anthropometric features, in order to present some of their anthropometric characteristics, from the tested entities we have extracted a group of 410 different athletes Since the athletes represent a group of entities with particular anthropometric features, in order to present some of their anthropometric characteristics, from the tested entities we have extracted a group of 410 different athletes (196 football sportsmen, 81 basketball sportsmen, 76 handball sportsmen, and 56 martial sportsmen). Based on the data of Table IV it can be defined some anthropometric characteristics of the Kosovo Albanian athlete, such as:

- Average Body Height $\mathrm{BH}=1847.75 \mathrm{~mm}$ (variation Min=1672 mm; Max=2150 mm);

- Average Body Weight BW=75.87 kg (variation Min=57.3kg; Max=125kg);

- $\quad$ Average Body Mass Index BMI $=22.2 \mathrm{~kg} / \mathrm{m}^{2}$ (variation Min $=15.7 \mathrm{~kg} / \mathrm{m}^{2}$, Maxi $=38 \mathrm{~kg} / \mathrm{m}^{2}$ );

- $\quad$ Average Basal Metabolic Rate BMR=1898.63 kcal (variation Mini=1629 kcal, Maxi=2670.55 kcal);

- $\quad$ Average Daily Energy Needs DEN=3966.77 kcal (variation Mini=3404.61 kcal, Maxi=5581.45 kcal).

These average anthropometric parameters allow us to conclude that sportsmen of Kosovo Albanian ethnicity belong to the category of tall people with ideal body weight and normal body mass index. 
Table III. Descriptive parameters of the BMI and the BMR for different age groups.

\begin{tabular}{|c|c|c|c|c|c|c|c|c|c|c|}
\hline \multicolumn{5}{|c|}{ BMI } & \multicolumn{4}{|c|}{ BMR } & \multirow[b]{2}{*}{$\begin{array}{l}\text { Std. } \\
\text { Dev. }\end{array}$} & \multirow[b]{2}{*}{$\begin{array}{l}\text { Correlation } \\
\text { BMI-BMR }\end{array}$} \\
\hline $\begin{array}{l}\text { Age } \\
\text { groups }\end{array}$ & $\mathrm{N}$ & Min & Max & Mean & $\begin{array}{l}\text { Std. } \\
\text { Dev. }\end{array}$ & Min & Max & Mean & & \\
\hline 6 & 117 & 11.99 & 26.70 & 15.12 & 2.26 & 779.38 & 1291.25 & 949.27 & 85.05 & 0.72 \\
\hline 7 & 353 & 11.80 & 26.77 & 15.37 & 2.29 & 818.75 & 1483.75 & 995.42 & 89.79 & 0.71 \\
\hline 8 & 664 & 8.54 & 25.45 & 16.00 & 2.47 & 830.63 & 1541.25 & 1058.48 & 93.85 & 0.76 \\
\hline 9 & 1286 & 9.78 & 34.06 & 16.51 & 2.94 & 765.00 & 1823.75 & 1117.90 & 110.33 & 0.77 \\
\hline 10 & 2236 & 8.74 & 33.03 & 17.02 & 2.83 & 875.63 & 1932.50 & 1176.28 & 117.46 & 0.78 \\
\hline 11 & 4877 & 8.04 & 46.15 & 17.32 & 2.92 & 845.00 & 2007.50 & 1228.85 & 120.12 & 0.77 \\
\hline 12 & 7838 & 11.70 & 40.48 & 17.71 & 2.83 & 946.25 & 2125.00 & 1289.11 & 128.53 & 0.75 \\
\hline 13 & 9130 & 11.53 & 34.71 & 18.31 & 2.81 & 820.63 & 2361.25 & 1375.11 & 149.34 & 0.75 \\
\hline 14 & 9196 & 10.35 & 43.66 & 19.05 & 2.73 & 1068.75 & 2316.88 & 1484.63 & 156.95 & 0.72 \\
\hline 15 & 9222 & 6.65 & 36.17 & 19.88 & 2.58 & 943.75 & 2371.25 & 1583.05 & 144.62 & 0.72 \\
\hline 16 & 8365 & 11.77 & 36.92 & 20.61 & 2.45 & 1156.88 & 2250.00 & 1649.76 & 124.94 & 0.69 \\
\hline 17 & 7205 & 8.52 & 39.61 & 21.13 & 2.35 & 1122.50 & 2403.13 & 1685.92 & 115.97 & 0.64 \\
\hline 18 & 6086 & 8.79 & 39.65 & 21.57 & 2.28 & 1280.63 & 2376.25 & 1708.87 & 113.24 & 0.63 \\
\hline 19 & 4958 & 8.81 & 40.28 & 21.94 & 2.14 & 1085.00 & 2375.63 & 1719.48 & 111.16 & 0.60 \\
\hline 20 & 3599 & 15.75 & 36.97 & 22.32 & 2.14 & 1296.25 & 2349.38 & 1732.38 & 112.19 & 0.57 \\
\hline 21 & 2783 & 13.22 & 50.62 & 22.68 & 2.33 & 1335.00 & 2698.75 & 1739.80 & 110.54 & 0.56 \\
\hline 22 & 2404 & 10.86 & 41.94 & 22.89 & 2.28 & 1347.50 & 2465.00 & 1743.67 & 114.30 & 0.59 \\
\hline 23 & 2036 & 10.39 & 37.40 & 23.30 & 2.45 & 1298.13 & 2367.50 & 1749.67 & 122.03 & 0.63 \\
\hline 24 & 1684 & 16.10 & 37.40 & 23.41 & 2.48 & 1411.25 & 2278.75 & 1751.29 & 122.15 & 0.63 \\
\hline 25 & 1423 & 16.48 & 38.32 & 23.54 & 2.46 & 1396.25 & 2417.50 & 1751.91 & 123.32 & 0.66 \\
\hline $26-29$ & 3601 & 15.99 & 46.12 & 24.10 & 2.64 & 1322.50 & 2760.00 & 1753.79 & 124.73 & 0.64 \\
\hline $30-39$ & 3049 & 16.55 & 42.37 & 24.96 & 2.89 & 1358.13 & 2615.00 & 1743.40 & 137.27 & 0.67 \\
\hline $40-49$ & 798 & 18.12 & 46.19 & 26.53 & 3.43 & 1396.88 & 2626.25 & 1739.81 & 156.23 & 0.79 \\
\hline $50-59$ & 125 & 17.44 & 42.74 & 28.94 & 4.39 & 1170.00 & 2211.25 & 1777.59 & 200.97 & 0.70 \\
\hline $60-69$ & 76 & 17.38 & 34.79 & 28.01 & 4.60 & 1216.88 & 2023.13 & 1618.02 & 196.29 & 0.79 \\
\hline$>70$ & 28 & 17.78 & 30.47 & 24.40 & 3.08 & 1175.63 & 1721.25 & 1353.06 & 143.24 & 0.77 \\
\hline
\end{tabular}

Table IV. Morpho-functional characteristics among sportsmen.

\begin{tabular}{llrrrr}
\hline & $\mathrm{N}$ & Min & Max & Mean & Std. Dev. \\
\hline Age & 410 & 15.00 & 25.00 & 19.51 & 2.22 \\
BH & 410 & 1672.00 & 2150.00 & 1847.75 & 7.28 \\
BW & 410 & 57.30 & 125.00 & 75.87 & 11.86 \\
BMI & 410 & 15.70 & 38.00 & 22.21 & 3.10 \\
BMR & 410 & 1629.00 & 2670.55 & 1898.63 & 178.65 \\
DEN & 410 & 3404.61 & 5581.45 & 3966.77 & 369.44 \\
\hline
\end{tabular}

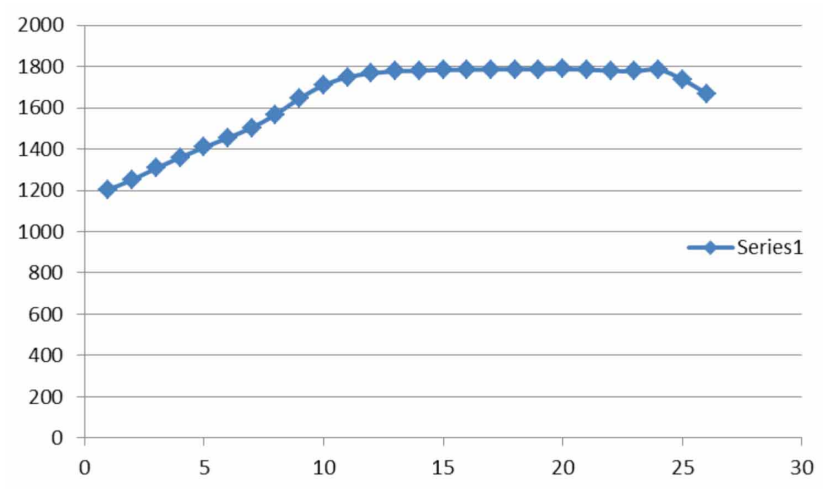

Fig. 2. Mean values of Body Height (BH).

\section{CONCLUSION}

Since thus far, standard (normative) values of Kosovo Albanian population have not been obtained, the data gained in this study may be considered as valid normative values of four anthropometric variables such as: Body Height (BH), Body Weight (BW), Body Mass Index (BMI) and Basal Metabolic Rate (BMR). According to the data of this study, some morphometric features of the Kosovo Albanian population aged 24-25 years old can be concluded, such as: the average to high body height, ideal body weight, and normal BMI. 
The higher values of the correlation coefficient between measured morphometric variables can be explained by the proportional changes of the Body Height and the Body Weight during the different age phases. The increased correlation between $\mathrm{BH}$ and $\mathrm{BW}$ in the two growth phases shows the increase (children and youth) respectively the proportional decrease of $\mathrm{BH}$ and $\mathrm{BW}$ values (old people) during the different phases of morphometric changes of the tested population. Increased values of BH and BW at age-group of 7-8 years old correspond with increased secretion of corticosteroid hormones which have an impact on the body's preparation for the puberty phase. Meanwhile, the increased of these variables at the agegroups of 13-15 years old corresponds to the onset of the vigorous period of puberty. The height of human being decrease with age increases as a result of hipercifosis (an increased curvature of the spine), decrease of the intervertebral spaces (the dehydration of the discs between vertebras), compression fracture (due to osteoporosis - bone demineralization), and loss of muscle also can contribute in decrease of the Body Height and the Body Weight.

Kosovo Albanian sportsmen aged 17-25 years with average Body Height $=1847.75 \mathrm{~mm}$ (variation mini $=1672 \mathrm{~mm}$, $\operatorname{maxi}=2150 \mathrm{~mm}$ ) and average Body Weight $=75.87 \mathrm{~kg}$ (variation mini= $57.3 \mathrm{~kg}$, maxi=125 $\mathrm{kg}$ ) belong to group of taller people with ideal body weight.

REXHEPI, A. M.; BRESTOVCI, B. \& ISUFI, I. Valores normales de algunas variables morfométricas para la población albanesa de Kosovo de edades entre los 6 y los 70 años. Int.J.Morphol., 36(1):592597,2018 .

RESUMEN: El objetivo de este estudio fue conocer los valores normales de la altura, el peso, el índice de masa corporal y la tasa metabólica basal, así como estudiar, observar y aclarar la dinámica del crecimiento y los cambios físicos. Se midieron cuatro variables antropométricas en 94825 personas albanesas de Kosovo de edades comprendidas entre los 6 y los 70 años, durante el período 2007-2016. Las mismas variables se midieron en 409 deportistas de Kosovo. Los datos obtenidos fueron analizados a través de parámetros descriptivos (media aritmética, máxima, mínima y desviación estándar) y análisis de correlación. Los resultados obtenidos indican una altura promedio de los varones albaneses de Kosovo $(50,6 \%$ de los grupos $=1700$ $1799 \mathrm{~mm}, 38,2 \%=1800-1899 \mathrm{~mm})$. El grupo menor con una altura corporal de $1015 \mathrm{~mm}$ pertenece al grupo etario de 6 años, mientras que el grupo superior con $2015 \mathrm{~mm}$ pertenece al grupo de edad de 19 años. El coeficiente de correlación entre la altura del cuerpo y el peso corporal muestra sus valores más altos en dos fases de crecimiento corporal intensivo $(0,71-0,76)$ y en la fase de disminución de la morfometría corporal $(0,57-0,65)$. Los deportistas albaneses de Kosovo de entre 17 y 25 años con una estatura corporal promedio $=1847,75$ $\mathrm{mm}$ y un peso corporal $=75,87 \mathrm{~kg}$ pertenecen al grupo de personas más altas con un peso corporal ideal.

PALABRAS CLAVE: Estatura corporal; Peso corporal; Índice de masa corporal; Tasa metabólica basal.

\section{REFERENCES}

Bray, G. A. Medical consequences of obesity. J. Clin. Endocrinol. Metab., 89(6):2583-9, 2004.

Coon, C. S. The mountains of giants, a racial and cultural study of the north Albanian mountain Ghegs. Cambridge (Mass.), Papers of the Peabody Museum of American Archaeology and Ethnology, Harvard University, vol. 22, no. 3, 1950.

Coon, C. S. The Races of Europe. $2^{\text {nd }}$ ed. New York, Macmillan, 1939. pp.293.

Dhima, A. Antropologjia Etnike e Shqiptareve. Tirana, UET Press, 2017. pp.9-14.

Enciclopedia Britanica. Illyrian Ancient People. 2017. Available from: https://www.britannica.com/topic/Illyrian Accessed

Fagaras, P. S.; Radu, L. E. \& Rus, M. C. Relation between body shape and body mass index. Procedia Soc. Behav. Sci., 197:1458-63, 2015.

Glück, L. Zur physischen anthropologie der Albanesen. Wissenschaften und Mitteilungen aus Bosnien und der Hercegovina, 5:365:402, 1897.

Herrera, B. M.; Keildson, S. \& Lindgren, C. M. Genetics and epigenetics of obesity. Maturitas, 69(1):41-9, 2011.

McEvoy, B. P. \& Visscher, P. M. Genetics of human height. Econ. Hum. Biol., 7(3):294-306, 2009.

Rexhepi, A. \& Brestovci, B, Differences in bodily growth between young footballers and basketball players. Int.J. Morphol., 28(2):415-20,2010.

Rexhepi, A. M.; Brestovci, B. \& Krasniqi, A. Physical characteristics at different ages. Int. J. Morphol., 29(1):105-11, 2011.

Sammalisto, S. Search for Genetic Variants Influencing Human Height. Academic Dissertation. Helsinki, National Public Health Institute, 2008. pp.16-22.

Wardle, J.; Carnell, S.; Haworth, C. M. \& Plomin, R. Evidence for a strong genetic influence on childhood adiposity despite the force of the obesogenic environment. Am. J. Clin. Nutr., 87(2):398-404, 2008.

Weisbach, A. Körpermessungen Verschiendener Menschenrassen. ZfE, Suppl./Band IX:213-25, 1877.

\author{
Corresponding author: \\ Agron M. Rexhepi \\ Rr. Sali Butka 10000 \\ Prishtina \\ Kosovo
}

Email: agronmrexhepi@gmail.com

Received: 03-12-2017

Accepted: 30-01-2018 